\title{
ONLY WAITRESS AT THE TRUCK-STOP WHO NEVER USES THE CASH REGISTER
}

\author{
岁 pamela \\ is half indian, \\ 플 gray-black hair \\ ₹ in a double braid \\ down her back. \\ every time \\ she serves me \\ another waitress \\ rings the ticket.
}

i figured

she was slow

or bad with numbers,

maybe had a

theft charge

in her past.

but yesterday

on my way out

she was sitting

on the

hood of her car

smoking a

cigarette. 
come here a sec

tell me

what this says,

she motioned over

and handed me

a white piece of paper

creased in thirds.

told me

she found it

taped to her

apartment door

that morning.

176

i told her

it was a note

from her landlord

saying she had

five business days

to get rid of

her dog.

she stood up

and snuffed out

the cigarette

with her heel. 
bear's been

with me

since idaho,

she said

and walked back in

leaving the note

in my hand. 